\title{
Skrif en Kerkorde
}

\author{
P C Coertzen
}

\section{ABSTRACT}

\section{Scripture and church order}

This article attempts to contribute to the clarification of the relationship between Scripture and church order. The concept church order is not considered to refer to rules and regulations only, but to encompass the entire nature of the church. In attempting to answer the question about the relationship between Scripture and church order, the author first sets out the views of a number of theologians on the issue and thereafter presents his perspective on the issue.

\section{TER INLEIDING}

Hierdie artikel wil die verhouding tussen Skrif en kerkorde ondersoek. Watter rol speel die Skrif ten opsigte van die orde in die kerk en hoé word die rol gespeel? Met kerkorde word nie net bedoel 'n bepaalde dokument wat ons as 'n kerkorde ken nie, dit gaan eintlik om die hele bestaan van die kerk as die kerk van Jesus Christus. Hoe moet die kerk lyk as dit werklik kerk van Christus wil wees? Dit bring ons dan by die vraag na welke rol die Skrif in die kerk se bestaan speel. Die vraag wat saamhang met die wese van die kerk as sodanig word hier dan veral uit die hoek van kerkreg en kerkregering benader.

In die beantwoording van die vraag gaan daar eerstens gekyk word na enkele resente en kontemporêre antwoorde. Daarna gaan daar getrag word om 'n paar lyne te trek wat moontlik vanuit 'n kerkregtelike hoek 'n bydrae kan lewer tot ' $n$ baie belangrike en noodsaaklike teologiese en kerklike gesprek. Wat hier gebied word, is voorlopige resultate en vorm deel van 'n voortgaande proses van navorsing oor 'n baie belangrike saak, nie net in kerkreg en kerkregering nie, maar in die teologie as geheel. 


\section{ENKELE RESENTE EN KONTEMPORERE STANDPUNTE OOR SKRIF EN KERKORDE}

\subsection{O Noordmans}

O Noordmans ${ }^{1}$ gee rekenskap van die wyse waarop die Skrif gelding het ten opsigte van die regering van die kerk. Hy formuleer sy standpunt teen die agtergrond van 'n artikel van $\mathrm{H}$ van der Linde oor "de hervormdekatholieke modaliteit" in Woord en Dienst van 20 September 1952. In die betrokke artikel beweer Van der Linde dat A M Brouwer op die eksegetiese moontlikheid en waarskynlikheid van 'n episkopale kerkorde gewys het en dat Noordmans daarop gereageer het met 'n diskwalifikasie van die betekenis van die herontdekte struktuurverbande in die Nuwe-Testamentiese teologie wat geen reformatoriese teoloog meer vir sy rekening sou wou neem nie.

Hierop reageer Noordmans dan deur daarop te wys dat vir Brouwer ${ }^{2}$ die kerkvorm 'n oorwegend praktiese aangeleentheid was "Welke (kerkvorm) wij voor ons volk en voor ons tijd verkiezen is een praktische, historisch te begronden vraag, maar kan niet regelrecht uit de bijbelse gegevens worden afgeleid". Hier is dus glad nie sprake daarvan dat Bouwer ywerig gebruik gemaak het van die herontdekte struktuurverbande in die Nuwe-Testamentiese teologie nie. Noordmans is van mening dat hy eerder die struktuurverbande vir die praktyk gediskwalifiseer het. Vir Brouwer was die afleidinge uit die Skrif ten opsigte van die orde in die kerk indirek en ook der mate inirek dat dit eintlik 'n suiwer praktiese aangeleentheid geword het. Of ' $n$ kerk 'n biskoplike of presbiteriale kerkregering kies, hang volgens Brouwer heeltemaal van historiese omstandighede af.

Noordmans self is ook van mening dat die afleiding van die kerkorde uit die Skrif indirek behoort te wees. Die dogmatiese gelding van die Nuwe Testament dra volgens hom 'n ander karakter as die bestuursgelding van die Nuwe Testament. Desnieteenstaande bly hy egter van mening dat die struktuurverbande van die Nuwe Testament steeds hulle gelding bly behou en dat dié gelding, hoe indirek ookal opgevat, nooit afdaal tot by die grens van blote saaklikheid nie: "Er is een structuur van het Lichaam van Christus, die in de Schrift mystisch gegeven is en die het laatste woord spreekt in het wereldhistorisch debat" 3 . Daar is na sy mening twee maniere om met die Skrif om te gaan ten opsigte van byvoorbeeld die vraag na ouderlinge in die kerk: die sogenaamde platvlak-metode of die metode van die derde dimensie. In die platvlak-metode sal daar bloot net nagegaan 
word waar daar orals presbiters of opsigters was en die gegewens sal dan dien as loca probantia (bewysplekke) vir die feit van 'n presbiteriale kerkregering. Soos wat hierdie metode, volgens Noordmans, nie meer in die dogmatiek aanvaarbaar is nie en as fundamentalisme afgewys word, so geld dit ook des te meer van die leer betreffende die kerk in sake die orde in die kerk. 'n Meerdere vorm van bewysvoering is volgens Noordmans nodig, 'n indirekte vlak van bewysvoering wat uit die plat vlak van die letterlik-historiese kan uitkom. Hierdie meerdere vorm van bewysvoering is dan die struktuur van die liggaam van Christus wat misties in die Skrif gegee is. Dit was hierdie tipe bewysvoering, volgens Noordmans, wat Calvyn daartoe gebring het om op die bord die pion van die ouderling te trek en die pous daarmee skaakmat te sit $^{4}$.

Noordmans skryf soos volg oor hierdie indirekte metode van afleiding uit die Skrif: "Onder 'indirect' versta ik hier dat het geen zaak is van letterkundig uitlegging alleen. Er komt Geest en geloof bij te pas; de nood is opgelegd. Daarom zou men het ook kunnen omkeren en zeggen dat dit juist de directe, regelrechte toepassing van de Schrift is, waarmee God beslag op ons legt zodat wij zeggen: ik kan niet anders" ${ }^{5}$. Noordmans staan baie sterk daarop, teenoor Brouwer, dat hierdie metode van afleiding van 'n kerklike orde uit die Skrif nie prakties van aard is nie. 'n Praktiese wyse van afleiding sou volgens hom beteken dat daar enige kant toe uitgegaan kan word met die gegewens van die Skrif, "dat God het bij wijze van spreken verder aan ons overlaat; dat de toepassing van de Schrift in verschillende richtingen kan plaatshebben en dat we een keus mogen doen uit een aantal mogelijke uitleggingen zonder dat een hogere noodzaak ons bindt" 6 . Volgens Noordmans het die eerste gereformeerdes hulle kerkorde met dieselfde sekerheid geskryf as warmee hulle hul geloofsbelydenis opgestel het. Hy haal Lechler met instemming aan as dié oor die eerste gereformeerde sinode skryf: "In hun beraadslagingen ligt een zedelijke eenvoud en grootheid die aangrijpend zijn, een rustige waardigheid, een vreedzame en besliste kracht alsof haar leden handelden in volle vrede, onder de bescherming van de wet, terwijl ze toch een bijna zekere dood trotseerden". Hierop laat Noordmans dan self volg: "Ze maken de indruk alsof ze een aantal bijbelse axioma's opschrijven. Zoals er boven de Tien geboden staat dat God Israel uit Egypteland uitgeleid heeft, zo staat boven deze kerkorden: geen kerk zal over een kerk, geen dienaar des Woords, geen ouderling noch diaken zal de een over de ander heerscappij voeren"?.

Baie belangrik in hierdie meerdere bewysvoering is die rol van die Heilige Gees. Hoewel daar van literêre en historiese vrae in die Nuwe Testament uitgegaan kan word, moet daar uiteindelik onder die leiding van 
die Heilige Gees gelet word op die struktuur van die liggaam van Christus in elke eeu en op die situasie van die heilige algemene christelike kerk in die wêreldgeskiedenis. Uiteindelik gaan dit om die liggaam van Christus wat werklik misties genoem moet word om geestelike argumente te voer wat die letter kan transendeer. Calvyn het dit gedoen toe hy hom na die reël van God gedra het en 'n kerkorde met mag daargestel het, anders as die priesters en die kanonici: "Had hij uit de nieuwtestamentische ambten en gaven de profeet op de voorgrond gebracht, dan was hij met de anabaptisten geestdrijver geworden. Had hij de opziener, de bischop gekozen, dan had hij de Geest weer uitgeblust. Nu schoof hij de presbyter op het kerkelijk bord naar voren. Dat deze de beslissende figuur was, kan wij vooral ook zien uit de wijze waarop de overheid daarop reageerde. Deze begreep volkomen dat Calvijn daarmee, in naam van Christus, beslag legde op een stuk mensenleven, waarover zij tot nog toe zeggenschap had gehad. Deze hervormer achte de opvolging van Jezus van minder betekenis dan het tegemoet gaan van Christus' wederkoms. En hij meende derhalve, dat er in de Una Sancta ruimte genoeg was om van de bisschop over te gaan op de presbyter, wiens ambt op die wederkomst gericht was" 8 . Hierdie optrede van Calvyn was volgens Noordmans eksegese in 'n hoër dimensie, waarby die Heilige Gees die uitlegger was. Wanneer dit gebeur, daag daar vir die kerk 'n beslissende uur op.

Dit is inderdaad so dat die kerkbegrip, of wat Noordmans dan noem die Nuwe-Testamentiese struktuurverbande, die misterie van die kerk as die liggaam van Christus, ' $n$ belangrike rol speel in die bepaling van die verhouding tussen Skrif en kerklike orde. Hierdie siening word ook, tot op 'n bepaalde hoogte, deur C J Smit gehandhaaf'. Dit is egter 'n vraag of daar nie nog agter die kerkbegrip na 'n dieper grondslag vir kerkreg en kerkregering in die Skrif self gesoek moet word nie. Dit bring egter die vraag van sogenaamde kerkregtelike fundamentalisme na vore, 'n vorm van omgaan met die Skrif wat Noordmans wil vermy. Dit is nie presies duidelik wat Noordmans met die begrip fundamentalisme bedoel nie. Hieroor sal nog verdere navorsing gedoen moet word. Dit is vir kerkreg en kerkregering in die geheel baie belangrik om hieroor duidelikheid te kry. M A Kruger wys onder meer op die gebruik om Skrifgedeeltes buite konteks aan te haal en tradisionalisme (dit wil sê dat die Skrif op blote menslike gesag aangehaal word en nie self ondersoek word nie) as kenmerke van fundamentalisme en toon dan eksplisiet aan hoe hierdie vorme van fundamentalisme in Gereformeerde kerkreg en kerkregering voorkom $^{10}$. Uit wat Noordmans skryf wil dit voorkom of hy met fundamentalisme 'n tipe Skrifgebruik bedoel wat bloot net op die vlak van die 
literêr-historiese met die Skrif omgaan en wat nie die teologiese en kerkhistoriese dimensies van die omgaan met 'n teks verreken nie. Volgens Polman is hierdie soort van omgaan met die Skrif 'n bepaalde vorm van biblisisme ${ }^{11}$. Noordmans se groot kritiek teen hierdie vorm van omgaan met die Skrif is dat dit aanleiding gee daartoe dat allerlei praktiese oorweginge uiteindelik bepalend raak vir wat van ' $n$ bepaalde teks in die regering van die kerk gemaak word. Dit is inderdaad ' $n$ vraag of baie van die kritiek teen fundamentalisme nie juis hier 'n punt 'n swakheid vertoon nie. In sommige gevalle is dit praktiese oorweginge wat deurslaggewend raak vir die orde in die kerk terwyl ander dit het oor 'n verskeidenheid van perspektiewe op die waarheid ${ }^{12}$. Wat duidelik is, is dat hier 'n gebied is waaroor daar nog verder gewerk sal moet word in die kerkreg.

\subsection{E Schillebeeckx}

In Kerkelijk ambt. Voorgangers in de gemeente van Christus het Schillebeeckx dit ook onder meer oor die wyse waarop die Skrif ten opsigte van die amp funksioneer. Volgens hom het dit in die bestaan van die NuweTestamentiese gemeenskappe spontaan om 'n selfverstaan gegaan en as sodanig het dit dan daartoe gelei dat die gemeentes hulle selfverstaan as die wil van die Here vir hulle ervaar en verklaar het: "Als echter volgens het zelfverstaan der eerste christenen de christelijke gemeente een 'gemeente van God' is en een 'tempel van de Heilige Geest', dan ligt het voor de hand dat wat spontaan van onderop ontstaat (nu zouden we zeggen: volgens de sociologische wetten van groepvorming) door de gemeenten uiteraard en terech, even spontaan, als 'gave van de heer' wordt ervaren en expliciet geïnterpreteerd (Ef 4,8-11; 1 Tim 4,14; 2 Tim 1,6)"13. Dit was eers later deur allerlei kerklike beslissings dat daar 'n teologie van die amp ontstaan het wat ver verwyderd was van die eerste eeue. Volgens hierdie teologie van die amp sou daar dan ' $n$ teenstelling wees tussen dit wat van onderaf uit die gemeente kom en dit wat van bo-af kom.

Schillebeeckx onderskei verder in die Nuwe Testament tussen twee periodes of fases, te wete die periode van die apostels en die periode van die ná-apostoliese tyd. In die tyd van die apostels het daar veral profete (wat ook sogenaamde entoesiaste ingesluit het) en leraars opgetree as leiers van plaaslike gemeentes ${ }^{14}$. In die tydperk ná die apostels onstaan die sogenaamde ampsprobleem: "De gangmakers van de gemeente waren gestorven; hoe moest het nu verder?"15. Die oplossing vir die probleem is daarin gesoek dat die "ampsdraers" (die leiers in die gemeente) ná die apostels, hulle self begin sien het as draers van die apostolisiteit van die 
gemeente ten einde daarin die waarborg te soek dat hulle waarlik die gemeente van Jeus Christus is en bly. Die ná-apostoliese leiers moes sorg vir die apostoliese "ervaringsoorsprong" waaruit die gemeente voortaan moes leef. Hulle moes met ander woorde sorg dra vir die identiteit van die gemeente ${ }^{16}$. Hierdie ampte is dan ook ervaar as besondere ampscharisma in diens van die gemeente. In die beginstadium, na die dood van die apostels, was die amp nog ingebed in die geheel van dienste wat vir die gemeente nodig was. Mettertyd het daar egter 'n institusionaliseringsproses plaasgevind wat veral daarin tot uitdrukking gekom het dat die inhoud van profeteer en onderrig in die begrip presbiter opgeneem is. In die Pastorale Briewe, die eerste brief van Petrus en die brief van Jakobus het ons voorbeelde van hierdie institusionaliseringsproses. Hulle is almal, volgens Schillebeeckx, ná-apostoliese briewe, geskryf deur gemeenteleiers wat in die briewe die selfverstaan van die betrokke gemeente weergee. Daarenteen blyk dit dat die evangelie van Matteus heeltemaal onbekend was met 'n presbiteriale orde in die kerk. By Johannes is daar wel presbiters, maar hulle het geen gesag nie ${ }^{17}$.

Uiteindelik kom alles, volgens Schillebeeckx, daarop neer dat daar in die Nuwe Testament verskillende ampsteologieë is wat volkome vryheid laat vir die konkrete strukturering van die amp in die kerk na die mate van die selfverstaan van die gemeente. Dit gaan om wat Schillebeeckx noem die apostolisiteit van die gemeente. Die amp is daar om die gemeente God se gemeente te laat wees en die gemeente by die apostoliese evangelie te hou, anders gestel, om die gemeente sy identiteit te laat behou maar daar moet ook ruimte wees vir wat Schillebeeckx noem "niet paulinisch georiënteerde gemeenten, die alle heil bleken te blijven zien in een louter charismatisch-ambtelijke leiding door de Geest" 18.

Die kritiek is al uitgespreek ${ }^{19}$ dat Schillebeeckx in sy ampsteologie nie genoegsaam rekening hou met die selfgetuienis van die Nuwe Testament self nie. Dit gaan immers nie in die Nuwe Testament om die selfverstaan van verskillende christelike gemeentes nie. Die Nuwe Testament is die gesagvolle getuienis van die apostels wat deur Christus daartoe die opdrag ontvang het. Hulle is deur die Heilige Gees daartoe gedryf. Dit beteken ook dat die eenheid van die Nuwe Testament baie belangrik is en aanvaar moet word en dat enige teoloog daarteen moet waak om oormoedig te wil bepaal wat van Paulus is en wat nie en hoe Lukas byvoorbeeld latere ontwikkelinge in die Handelinge van die Apostels ingeskryf het. Dit blyk immers onmiskenbaar uit Handelinge 14:23 dat die apostels alreeds presbiters geken het en dat hier nie van 'n ná-apostoliese ontwikkeling sprake is nie. Wat eintlik ook hier ter sprake kom, is die hele 
saak van historiese feit en interpretasie. Ten einde nie in die beperkte tyd en spasie te uitgebreid hieroor te skryf nie kan net daarop gewys word dat dit in die Skrif nie bloot net om historiese feite gaan nie, maar inderdaad om heilshistoriese feite. Wat in die Skrif opgeteken staan is inderdaad heilsgeskiedenis maar dit is net soseer heilsgeskiedenis want dit dui op God se dade van openbaring en verlossing in die geskiedenis. Dit gaan nie daarom dat die Skrif eers suiwer histories en/of sosiologies ondersoek en verklaar word en dat daar dan aan die einde van hierdie proses 'n geloofsprong in terme van 'n selfverstaan gemaak word nie. Die Skrif moet van die begin af ondersoek word in die geloof dat God Homself definitief in Jesus Christus openbaar het. Kerkregtelik beteken dit dat Jesus Christus inderdaad die Here en Hoof van sy kerk is. Hy het dit nie deur ' $n$ selfinterpretasie van die gemeente geword nie. Christus "gee" byvoorbeeld ampte as gawes in sy kerk, hulle is nie bloot net daar as gevolg van historiese en sosiologiese ontwikkelinge nie. Daar moet gewerk word met veronderstellinge wat aan die Skrif self ontleen word. Tereg skryf K Runia in dié verband: "M.A.W., we beginnen met het apriori des geloofs, met de erkenning, dat we deze bepaalde geschiedenis, die ons in de Bijbel verhaald wordt, aanvaarden als Gods geschiedenis met de mensen. Als iemand dit onwetenschappelijk wil noemen, betekent dit alleen maar dat hij zelf werkt met een zeer eng, $j a$ in feite met een positivistisch wetenschapsbegrip" 20 .

\subsection{K Runia}

Hoewel hy dit nie presies so stel nie lyk dit tog of Runia in Notities over de ambten in dieselfde rigting as Noordmans dink oor die wyse waarop daar met die Skrif omgegaan moet word in die regverdiging van die orde in die kerk. Hy begin sy argumentering deur kritiek te lewer teen die standpunt van 'n skrywer, wat hy nie by name noem nie, wat van mening is dat die ampsmodel en kerkmodel van die "jongste kerk" soos dit in die Nuwe Testament beskryf word, bindend is vir alle tye. Dit is vir die onvermelde skrywer, volgens Runia, die konsekwensie van die Sola Scriptura (die Skrif alleen) van die Reformasie ${ }^{21}$.

Runia self is egter van mening dat dit nie is wat met die Sola Scriptura van die Reformasie bedoel is nie. Luther was byvoorbeeld bereid om allerlei seremonies uit die middeleeuse kerk te behou solank dit nie die verkondiging van die genade in die weg gestaan het nie. Calvyn het wel die standpunt gehuldig dat ons in die erediens slegs dit mag doen wat duidelik voorgeskryf word in die Bybel. Terselfdertyd was hy egter ook bereid om bepaalde dinge te aanvaar wat in ' $n$ bepaalde tyd nuttig kon wees22. 
Volgens Runia het die reformatore hulle met die Sola Scriptura met name teen die Rooms Katolieke opvatting gerig dat naas die Skrif die tradisie van die ou kerk ook gesaghebbend is. Daarom is dit byvoorbeeld ook nie nodig om sekere dogmas vanuit die Skrif te bewys nie solank hulle maar net in die tradisie gefundeer is. Hierteen het Luther en Calvyn hulle verset. Wat geglo word mag slegs op die Skrif gegrond wees en wat nie op die Skrif gegrond is nie hoef ons nie te glo nie. Trouens, dit mag nie geglo word nie.

Wat die inrigting (orde) van die kerk betref, is dit egter heeltemaal anders gestel. Anders as in die Ou Testament, kry ons byvoorbeeld in die Nuwe Testament geen voorgeskrewe erediens en bindende voorskrifte nie. Trouens, in die Nuwe Testament blyk dit dat verskillende gemeentes verskillende strukture gehad het. Die christene uit die Jodendom het hulle van die begin af nou aangesluit by die sinagogale patroon terwyl die gemeentes van Paulus aanvanklik meer charismaties ingerig was. 'n Mens kry in die Nuwe Testament ook byvoorbeeld verskillende name vir verskillende funksies in die gemeente ${ }^{23}$.

Die kerk van vandag hoef dan ook nie die Nuwe-Testamentiese gemeente presies na te volg nie: "Wel moeten we proberen de grondlijnen voor het gemeentelijk leven, soals die in de verschillende vormen in het Nieuwe Testament aanwezig zijn, te vinden" 24 .

Wat die ampte betref, meen Runia dat daar toenemende konsensus tussen eksegete, beide van Rooms Katolieke en Protestantse kant bestaan dat die drie grondlyne (1) verkondiging en onderrig; (2) leiding en toesig en (3) diens is: "Wat dat betreft passen onze drie reformatorische ambten er precies bij: predikant, ouderling en diaken!" 25 .

Die vorm wat hierdie grondlyne binne 'n bepaalde historiese situasie aanneem, hang af van die tyd, kultuur en bepaalde nood wat bestaan. Daarom sou dit ook moontlik wees om in 'n nuwe situasie nuwe ampsvorme in te stel solank dit voldoen aan die norm van die gemelde grondlyne: "Welke vorm de ambten ook precies mogen hebben, ze behoren duidelijk in overeenstemming te zijn met de bijbelse grondlijnen" 26 .

Dit blyk uit die voorafgaande dat Runia ook nie van 'n sogenaamde direkte begronding vir die orde in die kerk gebruik wil maak nie. Waar Noordmans praat van die Nuwe-Testamentiese struktuurverbande het hy dit oor die norm van die grondlyne waaraan byvoorbeeld die ampsorde moet voldoen. Hy maak ook dieselfde onderskeid tussen die geloofsbegronding en die inrigting van die kerk as wat Noordmans maak.

'n Vraag sou oor hierdie laaste onderskeid gevra kon word. Terwyl dit toegegee moet word dat die Bybel nie op 'n biblisistiese manier hanteer 
moet word deur byvoorbeeld die kerk van die eerste eeu netso in die twintigste eeu te wil dupliseer nie; en terwyl toegegee moet word dat die tydomstandighede waarin die evangelie gestalte moet vind 'n baie belangrike rol speel in die bepaling van die vorm wat die kerk aanneem, moet dit tog ook gehandhaaf word dat daar die allernouste verband is tussen die inhoud van die geloof wat die Skrif aan ons voorhou en die konkrete vorm wat daardie geloof in die Nuwe-Testamentiese kerk aangeneem het. Daarom behoort dit ook nie onaanvaarbaar te wees om agter die struktuurverbande of grondlyne om, of wat dit ookal genoem word, te vra na die "direkte" Skriftuurlike begronding vir die orde wat geformuleer word nie. Dit kan trouens van die kerkregtelike verwag word om hom as wetenskaplike te verantwoord ten opsigte van die bron wat hy hanteer vir sy standpunte. As dit nie gedoen word nie is die gevaar van kerkordelike relativisme en subjektiwisme nie ondenkbaar nie. Dat Runia met hierdie moontlikheid rekening hou, blyk uit die feit dat hy tog die duidelike voorwaarde stel van: "Welke vorm de ambten ook precies mogen hebben, ze behooren duidelijk in overeenstemming te zijn met die bijbelse grondlijnen" 27 .

\section{SKRIF EN KERKORDE: 'N PAAR OORWEGINGS OM DIE VERHOUDING TE BEPAAL}

Die voor-die-handliggende vraag is hoe die Skrif in kerkreg en kerkregering hanteer moet word. Dit is moeilik om 'n klinklare antwoord op hierdie vraag te gee. Selfs al sou 'n presiese resep vir die hantering van die Skrif gegee kon word sou daar nog altyd die misterie van die Gees van God wees wat nie in mensewoorde gevat kan word nie. In gemeenskap met die Heilige Gees moet die reg vir die kerk in die Heilige Skrif gesoek, gevind, vergestalt en bedien word ${ }^{28}$.

Dit beteken na my mening dat die Heilige Skrif soos wat ons dit het, aanvaar moet word as die geopenbaarde Woord van God drie-enig, as die Woord wat deur God ge-adem is. Daar moet nie vooraf 'n klomp voorbehoude met betrekking tot die Skrif as die openbaring van God gestel word nie. Voorbehoude soos dat net sekere dele geïnspireerd sou wees; dat net die inhoud, maar nie die vorm nie openbaring is; dat wat ons as openbaring het eintlik maar net mense se weergawe is van wat hulle as die openbaring van God vertolk, of dat die uitsprake in die Skrif der mate gebonde is aan die tyd van hulle oorsprong dat ons die volste reg het om dit vandag totaal anders te vertolk in die lig van die besondere omstandighede wat ons vandag beleef of die ideale wat ons najaag. Om die Heilige Skrif as die ge- 
openbaarde Woord van God te aanvaar is uiteindelik ook nie maar net 'n voorbehoud van dié een wat die stelling maak nie. As dit die geval was sou daar uiteindelik nie veel verskil wees met al die ander voorbehoude nie. Die Heilige Skrif dien homself aan as die Woord van God en nie die woord van mense nie. In 2 Petrus 1:20-21 word gesê dat geen profesie in die Skrif op grond van eie insig reg uitgelê word nie, "want geen profesie is ooit deur die wil van 'n mens voortgebring nie. Nee, deur die Heilige Gees meegevoer, het die mense die woord wat van God kom, verkondig". Die Heilige Skrif in al sy verskeidenheid en vorme is die openbaring van God in Jesus Christus.

Terwyl die Heilige Skrif onverswak as die openbaring van God bely moet word, moet ons terselfdertyd in die hantering daarvan as bron vir die orde in die kerk verreken dat dit God se Woord in mensetaal is. God se Woord het inderdaad in die woorde, gedagtes en tye van mense ingegaan. Hiermee moet deurentyd rekening gehou word by die hantering van die Skrif as 'n bron vir kerklike orde. Dit beteken dat die hele Skrif steeds verklaar moet word met in agneming en verrekening van die tyd, die historiese moment waarin dit tot stand gekom het. Hierbenewens moet daar ook met die voortgang van die openbaring as sodanig rèkening gehou word. Weliswaar nie altyd 'n stygende lyn van voortgang nie, maar beslis 'n voortgang. Die implikasie hiervan, wat ook vir die orde in die kerk van belang is, is onder meer dat die woorde van Ou-Testamentiese skrywers nie só verklaar moet word asof die skrywers reeds Nuwe-Testamentiese kennis besit het nie. Waar die Ou-Testamentiese skrywers in verwagting vooruitgesien het na Christus, skryf die Nuwe-Testamentiese skrywers vanuit die werklikheid van die koms, sterwe en opstanding van Christus as die Here en Hoof van die kerk ${ }^{29}$. Die woorde van die Ou Testament moet steeds teologies, met in agneming van die bogenoemde, in hulle betrokkenheid op God drie-enig en in hulle heenwysing na Christus verklaar word. In hierdie lig gesien, is daar baie in die Ou Testament wat van die allergrootste betekenis vir die orde in die kerk is en dan beslis nie net in analogiese sin soos Nauta beweer nie.

Kennis van die historiese moment in die Skrif en die voortgang van die openbaring mag ook vir geen oomblik tekort doen aan die wesenlike eenheid van God se openbaring in die Heilige Skrif nie. Die Skrif is nie maar net 'n versameling van menslike geskrifte wat op verskillende oomblikke in die geskiedenis tot stand gekom het en wat ons gevolglik doodgewoon ook as sodanig kan hanteer in ons soeke na die orde vir die kerk nie. God is sowel die outeur as die wesenlike inhoud van die Skrif. In hierdie, wat ons kan noem, teosentriese karakter van die Skrif is ook die wesenlike eenheid van die Skrif gegee. 
In die allernouste verbintenis met die teosentriese karakter van die Skrif moet ons egter ook voortdurend onthou dat God Hom na die sondeval in sy besondere openbaring nie anders as in en deur die Middelaar geopenbaar het nie. Die Skrif is dus nie net 'n teosentries nie, maar ook 'n Christosentriese openbaring wat as bron vir die orde in die kerk hanteer moet word. Ons sou ook kon sê dat die Skrif ons kennis van God-inChristus openbaar. Ons kan dus aanvaar dat Jesus Christus en die betekenis van sy soenverdienste die eintlike skopus van beide die Ou en die Nuwe Testament is en vanuit die hele Openbaring moet die lyn altyd na Hom toe deurgetrek word. Die rigting wat deur die Skrif aangedui word, is inderdaad Christus se rigting en daarna moet die ganse gemeenskap van gelowiges deurentyd vra. Dit beteken egter nie dat die vorme van gehoorsaamheid soos ons dit in die Ou en Nuwe Testament aantref netso in ons dag gereproduseer moet word nie ${ }^{30}$.

Dit is nie die taak van Christusgehoorsame kerkregering om bepaalde historiese gestaltes van orde in die kerk ten alle koste te wil handhaaf nie. So 'n beskouing sou net tot tradisionalisme en uiteindelike verstarring lei. Sonder om die tradisie te verwaarloos of enigsins aan die geskiedenis verby te gaan - daar is inderdaad baie van te leer - mag hulle egter nooit normatief word vir die gestalte van gehoorsaamheid waaraan die orde van die kerk vandag moet voldoen nie.

Dit bring ons by 'n volgende saak waarmee daar steeds rekening gehou moet word in die vraag na hoe die Skrif hanteer moet word as bron vir kerkreg en kerkregering. Dit is naamlik die radikaliteit van die sonde. Dit mag nooit ' $n$ verskoning wees om nie na die wil van God in Christus te vra nie. Terselfdertyd moet die wete van die verwoestende gevolge en werking van die sonde en ons eie onheiligheid ons voortdurend waaksaam maak in die daarstelling van die orde in die kerk. Tereg is daar al gesê dat kerkreg die ootmoedige vraag na die wil van die Here vir sy kerk is ${ }^{31}$. Dit is egter nie vanselfsprekend dat die kerk 'n klinkklare insig in die Skrif het nie. Calvyn het met reg daarop gewys dat die feit dat die kerk in die Skrif heilig genoem word nie beteken dat die kerk in alle opsigte volmaak is nie. Christus het Homself inderdaad oorgegee om die kerk te heilig, maar Hy is ook elke dag besig met die gladmaak van die kerk se rimpels en die afwas van haar vlekke 32 . Wie dus in die Skrif gaan soek na God se orde vir sy kerk moet wysheid hê, insig in God se genade oor sy sondevervalle volk. Dit beteken uit die aard van die saak dat hulle wat na die orde van God soek baie moet bid. Bid vir die wysheid waardeur die leiding van die Gees deur die Woord herken mag word (Ef 1:15-23; 3:16-20). Die orde vir die kerk moet uiteindelik met in agneming van al bogenoemde in die Skrif 
gevind word. Wolf ${ }^{33}$ praat van die Skrifduidinge as "Biblische Weisung" wat grenstrekkend, grondliggend en doelwysend hanteer moet word. Nauta ${ }^{34}$ op sy beurt praat van die riglyne wat daar in die Skrif gegee word en wat met die nodige onderskeiding aangewend word. Smit staan baie sterk daarop dat die orde vir die kerk in die Skrif gevind moet word en dat die kerkreg daarom wesenlik uitleg en verkondiging van die Woord van die Here is. Om hierdie rede handhaaf hy ook 'n baie sterk standpunt dat kerkvergaderinge - 'n mens sou in hierdie verband ook sou kon verwys na die kerkregtelikes - nie regsvormende organe is nie, maar regsbedienende organe. Hulle bedien eintlik net die reg van Christus wat in die Skrif gegee is ${ }^{35}$. Die feit bly dat die vraag na die verhouding tussen Goddelike reg en die kerklike orde nie maklik uit te maak is nie. Dit is nie altyd so eenvoudig as om maar net God se reg uit die Woord te bedien nie. Dit is ook nie altyd voldoende om net te sê dat die weg van die Skrif gevolg is nie. Die vraag is inderdaad hoe hoor en hanteer ons die Skrif in die orde van die kerk. Wat hierbo gesê is, is 'n poging om teologiese-verantwoorde aanduiders te formuleer wat ons kan help om Christus se hoofskap van sy kerk onverswak te handhaaf. En wanneer Christus se stem in sy Woord gehoor is, moet dit konkreet tot uitdrukking kom in die kerklike orde wat op 'n gegewe historiese oomblik binne 'n bepaalde kerklike gemeenskap geld. Op dieselfde historiese oomblik waarop die reg vanuit die Woord geformuleer word, moet daar egter ook 'n deurlopende proses in werking tree waardeur die geformu-leerde orde steeds wéér en wéér in biddende afhankliheid van die Heilige Gees aan die Skrifopenbaring getoets te word ten einde seker te maak dat dit as kerklike orde nooit 'n grootheid teenoor die openbaring word wat as sodanig te kort doen aan die werklikheid van Christus se hoof- en heerskap in sy kerk en koninkryk nie.

\section{NOTAS:}

10 Noordmans, "Paulus komt en Petrus gaat" in: Verzamelde werken, 1 VIII, Kampen 1980, 324vv.

2 A M Brouwer, De Kerkorganisatie der eerste eeuw en wij, Baarn sj, 131.

3 Noordmans, a $w, 1980,434$.

$4 \quad$ Noordmans, $a w, 1980,434$.

5 Noordmans, "Kerkorde en beroep op de Schrift", in: Verzamelde werken deel V, Kampen 1984, 394. 
$6 \quad$ Noordmans, $a w, 1984,394$.

$7 \quad$ Noordmans, $a w, 1984,394$.

$8 \quad$ Noordmans, $a w, 1980,436$.

9 C J Smit, “Kerkorde en die Heilige Skrif - 'n Contradictio in terminus?", In die Skriflig 17 (1983), 35.

10 M A Kruger, Escaping the domination of the historical-critical method. Fundamentalism, and genitive theologies. Referaat gelewer by die Internasionale Teologiese Konferensie: The vitality of Reformed Theology, Noordwijkerhout, Nederland, 20-24 Junie 1994, 9-13.

11 A D R Polman, “Biblicisme”, Christelijke Encyclopaedie I, Kampen 1956, 615.

12 F Deist, "Fundamentalisme - 'n Gereformeerde beoordeling", Theologia Evangelica $12 / 2$ (1989), 6.

13 E Schillebeeckx, Kerkelijk ambt. Voorgangers in de gemeente van Christus, Bloemendaal 1980, 13.

14 Schillebeeckx, $a w, 16-19$.

15 Schillebeeckx, $a w, 19$.

16 Schillebeeckx, $a w, 20-21$.

17 Schillebeeckx, $a w, 27-35$.

18 Schillebeeckx, $a w, 30-31$.

19 A N Hendriks, "Schillebeeckx over het Ambt", in: Om de bediening van de Geest, Kampen 1983, 39.

20 K Runia, Prediking en historisch-kritisch onderzoek, Kampen 1972, 16.

21 K Runia, Notities over de ambten, Kampen 1992, 14.

22 Runia, $a w, 1992,15$.

23 Runia, $a w, 1992,15$.

24 Runia, $a w, 1992,15$.

$25 \quad$ Runia, $a w, 1992,16$. 
26 Runia, $a w, 1992,16$.

$27 \quad$ Runia, $a w, 1992,16$.

28 K Barth, Die Ordnung der Gemeinde. Zur Dogmatischen Grundlegung des Kirchenrechts, München 1955, 14.

29 P A Verhoef, Metodiek van die Eksegese. Kaapstad 1973, 61-72. Vergelyk ook A J Bronkhorst, Schrift en kerkorde. Een bijdrage tot het onderzoek naar de mogelijkheid van een "Schriftuurlijke kerkorde", Den Haag 1949, 47-48.

30 Barth, $a w, 15-16$.

31 C J Smit, "Kerkreg en kerkorde in diens van kerkregering. 'n Oorsig oor 'n beskouing”, In die Skriflig 21 (1987), 22.

32 J Calvyn, sj. Institutie of onderwijzing in de Christelijke godstdienst, II en III (Vertaler A Sizoo), Delft, IV sj, 1, 17.

33 E Wolf, "Zur Frage nach der Autorität der Bibel für die Rechtsordnung", in: Rechtstheologische Studien, Frankfurt 1972, 93vv.

34 D Nauta, Verklaring van de kerkorde van de Gereformeerde Kerken in Nederland, Kampen 1971, 17.

35 Smit, $a w, 1987,22$. 